\title{
Kuinka vasikat oppivat käyttämään juottoautomaattia?
}

Helena Hepola ${ }^{1)^{*}}$, Laura Hänninen ${ }^{2)^{*}}$, Satu Raussi ${ }^{3)^{*}}$, Sanni Heinonen ${ }^{1)}$, Juha Sariola ${ }^{3)}$, Hannele Khalili $^{3)}$ ja Hannu Saloniemi ${ }^{2 *}$

1) Kotieläintieteen laitos, PL 28,00014 Helsingin yliopisto, etunimi.sukunimi@helsinki.fi

2) Kliinisen eläinlääketieteen laitos, PL 57,00014 Helsingin yliopisto, etunimi.sukunimi@helsinki.fi

3)Maa-ja elintarviketalouden tutkimuskeskus,31600Jokioinen, etunimi.sukunimi@mtt.fi

Eläinten hyvinvoinnin tutkimuskeskus

Vasikoiden alkukasvatuksen vaikutuksesta juottoautomaatin käytön oppimiseen on vain vähän tietoa. Tiedetään, että emäänsä imeneet vasikat ovat oppineet paremmin imemään imettäjälehmää kuin tuttiämpäristä juoneet. Ei ole tutkittua tietoa, kuinka varhainen imemiskokemus vaikuttaa vasikoiden juottoautomaatin käytön oppimiseen. Emänsä kanssa olleet vasikat eivät ole tottuneet ihmisen käsittelyyn niin kuin yksilökarsinaan juotetut vasikat. Tämä voi vaikeuttaa vasikoiden opettamista juottoautomaatin käyttöön.

Jokioisissa Minkiön tutkimusnavetassa tehtiin koe, jossa 41 vasikkaa blokitettiin syntymäjärjestyksessä ja arvottiin satunnaisesti koeryhmiin. Neljän ensimmäisen poikimisen jälkeisen päivän ajan vasikat olivat joko emänsä kanssa poikimiskarsinassa (EMO) tai yksilökarsinoissa, joissa saivat ternimaidon joko avoimesta ämpäristä (ÄMPÄRI) tai tuttiämpäristä (TUTTI). Ternimaitokauden jälkeisenä aamuna n. klo 7.30 (testipäivä 1) yksi vasikka jokaisesta koeryhmästä laitettiin juottoautomaattikarsinaan, jossa oli ennestään kuusi kokenutta vasikkaa (kaksi kustakin käsittelystä, ikä $21 \pm 2$ pv). Jos vasikat eivät olleet kertaakaan onnistuneesti juoneet itse juottoautomaatista, ne ohjattiin automaatille klo 12.30. Seuraavan kerran vasikat ohjattiin automaatille tarvittaessa klo 17.30 ja seuraavana aamuna klo 7.30 jne.

Juottoautomaatin antamista tiedoista laskettiin keskimääräisen juontikerran pituus ja juontimäärät neljän ensimmäisen päivän aikana. Juottoautomaattia videoitiin 48 ensimmäistä tuntia. Videoista rekisteröitiin vasikoiden viettämä aika juottoautomaatin ovensuulla, kun automaatti oli tyhjä tai siellä oli toinen vasikka/hoitaja (suhteessa ovella vietettyyn kokonaisaikaan). Lisäksi laskettiin opetuskertojen määrät. Kolme vanhinta vasikkaa (yksi kustakin käsittelystä) siirrettiin pois karsinasta testipäivänä 4 . Ryhmien väliset erot testattiin sekamallilla.

Ensimmäisenä päivänä TUTTI -vasikat olivat juottoautomaatin ovensuussa enemmän kuin EMOtai ÄMPÄRI- vasikat silloin, kun hoitaja oli automaatissa opettamassa toisia vasikoita ( $16 \pm 7 \%$ ja $1 \pm$ $0.5 \%$ tai $5 \pm 3 \%, \mathrm{p}=0.009$ ja $\mathrm{p}=0.05$.). Toisena päivänä suurempi osuus EMO- vasikoista tarvitsi opetusta juottoautomaatin käyttöön kuin TUTTI- ja ÄMPÄRI - vasikoista (77 \% ja $36 \%$ tai $43 \%$, $\mathrm{p}=0.07)$. TUTTI -vasikat joivat kahtena ensimmäisenä päivänä nopeammin kuin muiden ryhmien vasikat. Maidonkulutuksessa ei havaittu eroja käsittelyjen välillä.

Tuttiämpäristä juoneet vasikat käyttivät juottoautomaatin tuttia tehokkaammin kuin avoämpäristä juoneet tai emosta imeneet vasikat. Maidon juominen imemällä oli yksilökarsinoiden vasikoille kenties palkitsevampi kokemus kuin juominen avoämpäristä ja vasikat leimautuivat vahvemmin ihmiseen. Vieroitus emästä ja vähäinen ihmiskontakti lienee vaikeuttanut emon alla pidettyjen vasikoiden oppimista.

Asiasanat: vasikka, juottoautomaatti, oppiminen 